\author{
Anna Pyrkosz \\ Uniwersytet im. Adama Mickiewicza w Poznaniu (doktorantka)
}

\title{
Asymilacje pod względem dźwięczności w grupach spółgłoskowych w polszczyźnie XVI i pierwszej połowy XVII wieku (na podstawie druków krakowskich)
}

Nadrzędnym celem niniejszego artykułu jest zobrazowanie problemu upodobnień występujących w grupach spółgłoskowych w szesnasto- i siedemnastowiecznej polszczyźnie. Istotne będą również określenie stopnia normalizacji języka w tym zakresie i kształtowanie się uzusu ortograficznego w obrębie grup. Wykorzystane będzie w tym celu zarówno ujęcie synchroniczne, pozwalające na określenie tendencji w danym okresie badawczym oraz w poszczególnych drukarniach, jak i ujęcie diachroniczne, umożliwiające prześledzenie zmian zachodzących wraz z upływem czasu. Omówiony zostanie także problem struktury grup spółgłoskowych, w których obrębie odnotowano przykłady asymilacji, frekwencji tego zjawiska, a także leksykalizacji. Z dużego materiału badawczego wyselekcjonowano grupy, których postać wyjściowa (przed asymilacją) jest zgodna ze stanem współczesnym, i w obrębie tak dobranego materiału zbadano tendencje do ubezdźwięcznień oraz udźwięcznień.

Podstawę materiałową badań stanowi dwanaście druków wydanych w oficynach krakowskich. W związku z tym, że kwestia asymilacji stanowi jeden z wielu problemów badawczych związanych z kształtowaniem się zwyczajów piśmienniczych w obrębie grup spółgłoskowych, na potrzeby omawianego zagadnienia szczegółowego nie ekscerpowano całych tekstów, lecz wyznaczano w każdym losowo trzy próby po tysiąc wyrazów. Cały badany okres (półtora wieku) podzielono na trzy odcinki: pierwszy - O1 (lata 1501-1550), drugi O2 (lata 1551-1600) oraz trzeci - O3 (lata 1601-1650).

Do O1 zakwalifikowano:

1. Druki wydane przez Jana Hallera: 
a) Agenda Latino et Vulgari Sermone Polonico Videlicet et Alemanico Illuminata, Jan Haller, Kraków 1514 (polskie fragmenty) - skrót: HalAg;

b) Powieść o Papieżu Urbanie, w: Agenda Latino et Vulgari Sermone Polonico Videlicet et Alemanico Illuminata, Jan Haller, Kraków $1514^{1}$ - skrót: HalUrb;

c) Poczatek święte ewanielije podtug świętego Jana, w: Septem canonicae epistolae beatorum apostolorum iacobi, petri, ioannis et iudae, Jan Haller, Kraków 1518/1519² - skrót: HalEw;

2. B. Opec, Zywot wszechmocnego Syna Bożego Pana Iezu Krysta, Hieronim Wietor, Kraków 1522 - skrót: OpZyw;

3. S. Falimirz, O ziolach y moczy gich, Florian Ungler, Kraków 1534 skrót: FalZio;

4. Tobias patriarcha starego zakonu z łaczinskiego ięzika na polski nowo a pilnie przełożony..., Maciej Ostrogórski (Scharffenberg), Kraków 1539 skrót: Tob;

5. P. Crescentiis, Księgi o gospodarstwie, Helena Florianowa (Unglerowa), Kraków 1534 - skrót: CresKs.

Do O2 zaliczono:

1. J. Mrowiński, Stadło matżeńskie z gron a źiarnek słowa Bozego, Łazarz Andrysowic, Kraków 1561 - skrót: MrowSta;

2. M. Siennik, Herbarz ziół tutecznych, Mikołaj Szarfenberg, Kraków 1568 - skrót: SienHerb;

3. P. Skarga, Zywoty Swiętych Starego y nowego zakonu, Andrzej Piotrkowczyk, Kraków 1585 - skrót: SkarZyw;

4. Philopolites, To iest miłosnik oycżyzny albo o powinności dobrego obywatela, Maciej Wirzbięta, Kraków 1588 - skrót: PhilMił.

Do $\mathrm{O} 3$ zakwalifikowano:

1. M. Łaszcz, Svmmarivsz prawdy katholickiey w przednieyszych sporach, Bazyli Skalski, Kraków 1607 - skrót: ŁaszSum;

2. Ząmbkowic, Młot na czarownice, Symon Kempini, Kraków 1614 skrót: ZąbMł;

3. Bernard z Clairvaux, Sposób madrego y dobrego życia na świecie, Franciszek Cezary, Kraków 1630 - skrót: BernSp;

4. M. Cichowski, Wizervnk nieprawdy arryańskiey, Walerian Piątkowski, Kraków 1650 - skrót: CichWiz.

${ }^{1}$ Cyt. za: W. Wydra, W.R. Rzepka, Chrestomatia staropolska-teksty do roku 1543, wyd. 2, Wrocław 2004.

2 Cyt. za: ibidem. 
Dodatkowy materiał badawczy, stanowiący tło do porównań, pochodzi ze Słownika polszczyzny XVI wieku . Jako podstawę badań obrano tylko teksty krakowskie. Ze względu na Akademię Krakowską oraz dwór królewski miasto to stanowiło centrum umysłowe kraju. To właśnie tutaj rynek książki był najlepiej rozwinięty, kształtowały się postawy czytelnicze i zwyczaje drukarskie:

Wyjątkowa rola przypadła Krakowowi dzięki drukarniom i drukarzom. Wielkie skupienie drukarni właśnie w tym mieście (ogółem 18 „firm” przy 4 w innych miejscowościach Małopolski) sprawia, że Kraków dzierży prymat pod tym względem w skali ogólnopolskiej, co - rzecz oczywista - w konsekwencji ma pierwszorzędne znaczenie dla rozwoju piśmiennictwa i dla kształtowania się języka literackiego, szczególnie jeśli zważyć znane ambicje i zabiegi drukarzy, by wywierać wpływ na te sprawy ${ }^{4}$.

Poza tym Kraków, ze względu na liczbę wydawnictw, dawał szersze możliwości przyuczenia się do zawodu osobom spoza tego miasta. Wypracowane i sprawdzone tam rozwiązania mogły być powielane w oficynach innych regionów. Prawie każde z ogniw łańcucha wydawniczego miało udział w kształtowaniu tekstu książki, jednak to drukarz wpływał na ostateczną jego postać. To on był pośrednikiem między autorem a odbiorcą - i to on musiał przystosować tekst autorski pod względem ortograficznym i graficznym do wymagań i przyzwyczajeń swoich klientów, tak aby ci nie mieli problemów z jego odczytywaniem. Język druków stanowi zatem, rzec można, odbicie ówczesnego uzusu językowego i pozwala obserwować zachodzące w nim zmiany.

Jedną z zauważalnych w polszczyźnie XVI oraz XVII wieku tendencji jest odchodzenie od pisowni etymologicznej ku fonetycznej, a więc zgodnej z wymową. Asymilacje fonetyczne polegają na częściowym lub pełnym dostosowaniu artykulacji danej głoski do artykulacji głosek sąsiednich. Wyróżnia się upodobnienia postępowe (progresywne), następujące pod wpływem poprzedzającej głoski, oraz wsteczne (regresywne), zachodzące pod wpływem głoski następującej. Mogą to być asymilacje pod względem dźwięczności, miejsca artykulacji i sposobu artykulacji, mogą obejmować połączenia międzywyrazowe i wewnątrzwyrazowe ${ }^{5}$. W tekstach każdego z badanych okresów moż-

${ }^{3}$ Stownik polszczyzny XVI wieku, red. M.R. Mayenowa, t. 1-32, Wrocław-Warszawa 1966-2004. W związku z tym, że materiał słownikowy nie daje możliwości kompleksowego badania zjawisk fonetycznych zachodzących w grupach spółgłoskowych, może być on traktowany tylko jako tło porównawcze.

${ }^{4}$ Z. Florczak, Udziat regionów w ksztaltowaniu się piśmiennictwa polskiego XVI wieku. Studium z zakresu socjologii pisarstwa, Wrocław 1967, s. 40.

${ }^{5} \mathrm{Na}$ podstawie: Upodobnienia fonetyczne [hasło], w: Encyklopedia języka polskiego, wyd. 3 popr. i uzup., Wrocław 1999. 
na odnaleźć przykłady asymilacji pod względem dźwięczności zarówno wewnątrzwyrazowych, jak i międzywyrazowych. Witold Mańczak, nawiązując do problemu asymilacji fonetycznych, stwierdza, że:

Obok nieregularnego rozwoju fonetycznego spowodowanego frekwencją istnieje inny, od dawna znany nieprawidłowy rozwój fonetyczny, na który składają się asymilacje, dysymilacje, metatezy, zmiany spowodowane ekspresywnością czy hiperpoprawnością. Otóż zmiany te mają to do siebie, że w różnych językach zachodzą one w najprzeróżniejszych wyrazach. Np. polski zmierzch (z ch zamiast $k$ ) wykazuje nieregularną zmianę spowodowaną hiperpoprawnością, ale wątpliwe jest, czy w jakim innym języku indoeuropejskim wyraz o tym znaczeniu uległ również zmianie spowodowanej hiperpoprawnością. W pol. pokrzywa zaszła metateza i znowu możliwe jest, że mało jest języków na świecie, w których by wyraz o tym znaczeniu uległ metatezie. W niektórych gwarach polskich w przypadkach zależnych od las zachodzi podwojenie spółgłoski, np. lassa, thumaczone ekspresywnością. I znowu zachodzi możliwość, że zmiana ta jest zjawiskiem odosobnionym, że nie ma innego języka indoeuropejskiego, w którym by wyraz znaczący 'las' wykazywał rozwój spowodowany ekspresywnością. W pol. księga zaszła dysymilacja $n$, które przed nosówką zmieniło się w ś. I znowu nie jest wykluczone, że w żadnym innym języku indoeuropejskim w wyrazie o tym znaczeniu nie zaszła dysymilacja. Tymczasem nieregularne zmiany spowodowane frekwencją charakteryzują się tym, że w różnych językach często przebiegają paralelnie, co się tłumaczy faktem, że pomimo różnic, jakie dzielą społeczności językowe, najczęściej używane wyrazy są wszędzie mniej więcej takie same ${ }^{6}$.

W poddanych analizie tekstach XVI i pierwszej połowy XVII wieku zdecydowanie dominują ubezdźwięcznienia7. W pierwszym okresie badawczym stanowią one około 2,1\% wszystkich zapisów grup spółgłoskowych niejednorodnych pod względem dźwięczności. W O2 zauważalne jest osłabienie tendencji: zapisy z asymilacją pod względem dźwięczności to 1,5\% odnotowanych grup spółgłoskowych. W ostatnim z badanych okresów znaleziono najmniej przykładów. Stanowią one zaledwie 0,3\% analizowanego materiału. Rozpatrując jednak tendencje indywidualne widoczne w drukach oraz tendencje szczegółowe kolejnych okresów badawczych, oprócz podobieństw można oczywiście znaleźć także różnice.

W drukach pierwszej połowy XVI wieku znalazło się 85 poświadczeń ubezdźwięcznień. Najwięcej przykładów wystąpiło w tekstach pochodzących

${ }^{6}$ W. Mańczak, Stowiańska fonetyka historyczna a frekwencja, Kraków 1974, s. 21.

${ }^{7} \mathrm{~W}$ tej części pracy nie uwzględniam ubezdźwięcznień międzywyrazowych. Ten typ ubezdźwięcznień zostanie, ze względu na swoją specyfikę, omówiony w oddzielnym punkcie i nie będzie brany pod uwagę w ogólnych obliczeniach statystycznych dotyczących ubezdźwięcznień. 
z oficyny Jana Hallera. Zapisy te stanowią 2,7\% odnotowanych w jego drukach niejednorodnych grup spółgłoskowych. Próba tekstu wydanego w oficynie Hieronima Wietora poświadcza 29 ubezdźwięcznień, co stanowi 3\% wszystkich zapisów. W druku Heleny Unglerowej znaleziono 18 potwierdzeń $(2,2 \%)$, podobnie w książce drukowanej u Floriana Unglera - 17 (2,1\%). Najmniej wypadków asymilacji odnaleziono w tekście drukowanym w 1534 roku u Macieja Scharffenberga (Ostrogórskiego) - zaledwie 7, co stanowi 0,7\% wszystkich zapisów.

We wszystkich tekstach pierwszego okresu badawczego najbardziej podatna na ubezdźwięcznienia jest spółgłoska $z$ występująca przed głoską bezdźwięczną w przedrostku roz-. W najstarszych drukach wydanych u Hallera odnotowano dwa takie wypadki: rofzpaczacz (HalUrb 312) ${ }^{8}$ i rofzschyrzycz (HalUrb 312). Nie znaleziono zapisów opozycyjnych tych leksemów, jak również innych $\mathrm{z}$ dźwięczną głoską $\mathrm{w}$ tym przedrostku. W wypadku tekstu pochodzącego z oficyny Wietora odnotowano 8 przykładów asymilacji występującej w 4 leksemach: rofkoff - 4 potwierdzenia (OpZyw 20a, 20b, 51a, 51b), rofpále - 2 (OpZyw 20a, 20b) oraz pojedyncze poświadczenia rofpámiętawffy (OpZyw 51b), rofpláczy (OpZyw 50a). W Zywocie wszechmocnego Syna Bożego... znaleziono jeden zapis opozycyjny z głoską dźwięczną: rozpámiętaw Jfy (OpZyw 100a). W druku pochodzącym z oficyny Unglera odnotowano 9 potwierdzeń z ubezdźwięcznieniem występującym w 5 leksemach: ro/pędzać - 3 poświadczenia (FalZio 101a, 104a, 202a), rofpadliny - 2 (FalZio 101a, 200b), rofpufzcża-2 (FalZio 204a, 204b) oraz pojedyncze zapisy - rofchodnikowe ${ }^{\circ}$ (FalZio 102a), rofprzeftrzenia (FalZio 204b). W obrębie próby tekstu wystapił jeden zapis bez ubezdźwięcznienia: roztartfzy (FalZio 402a). W tekście Tobias patriarcha..., który został wydany w 1539 roku w drukarni Macieja Scharffenberga, odnotowano 4 potwierdzenia asymilacji pod względem dźwięczności występujące $\mathrm{w}$ dwóch leksemach: ro/proffyt - 3 potwierdzenia (Tob 8, 30, 33), rofkazat - 1 (Tob 22). W analizowanej próbie tekstu wydanego u Macieja Scharffenberga nie pojawiły się zapisy ze spółgłoską dźwięczną (przed bezdźwięczna) w przedrostku roz-. W najmłodszym tekście pierwszego okresu badawczego, pochodzącym z oficyny Heleny Unglerowej, odnotowano 11 przykładów ubezdźwięcznień, które występują w 5 leksemach: roskofz - 7 zapisów (CresKs, np. 676, 677, 678) i pojedyncze potwierdzenia rofprawuiq (CresKs 326), rofpuka (CresKs 325), rofpufzcżano (CresKs 326), roffzyrza (CresKs 676). W druku tym wystapiło też najwięcej zapisów opozycyjnych - aż 7 poświadczeń w 6 wyrazach: rozplywała -2 potwierdzenia (CresKs 132 2r.) oraz pojedyncze zapisy leksemów: rozchodzqc (CresKs 134),

\footnotetext{
${ }^{8}$ Lokalizuję jednostki, podając skrót pozycji i numer strony.
} 
rozkofzne (CresKs 328), rozpufcżaiqcego (CresKs 135), rozfciełać (CresKs 679), roztwarza (CresKs 132). W druku Unglerowej zauważyć zatem można zdecydowanie niższy poziom stabilizacji $\mathrm{w}$ zakresie stosowania głoski dźwięcznej bądź bezdźwięcznej w przedrostku roz-. W pozostałych tekstach tego okresu formy z ubezdźwięcznieniem stanowią bezwzględną dominantę.

W obrębie druków wydanych w pierwszej połowie XVI wieku ubezdźwięczniana jest również grupa $-\dot{z} k$-. Najwięcej poświadczeń asymilacji w tej grupie występuje w wyrazie ciężko. Leksem ten pojawia się w druku Hallera (2 potwierdzenia - HalUrb 311 2r.), Wietora (6 - OpZyw 21a, 51a, 100a, 101a, 101b, 102a) i Unglera (4 - FalZio 100b, 101b, 103a, 405a). W tekstach tych wystapiły wyłącznie zapisy potwierdzające asymilację pod względem dźwięczności, czyli cięzzko. Grupę tę ubezdźwięczniano również w wyrazach fćiefzkach (Unglerowa - 1 potwierdzenie, CresKs 323) oraz tyfzkę (Ungler 1 potwierdzenie, FalZio 101b). Również w tych wypadkach nie wystapiły zapisy opozycyjne. $\mathrm{W}$ drukach $\mathrm{z}$ pierwszego okresu badawczego odnotowano 4 zapisy różnych wyrazów, w których w obrębie grupy -żk- nie doszło do asymilacji: wieżkę (CresKs 328), iakieżkolwie (CresKs 328), porażka (FalZio 405a) oraz ktożkolwiek (Tob 11). Zapisy wieżkę i iakieżkolwie, występujące w Ksiegach o gospodarstwie, potwierdzają zauważone wcześniej tendencje do stosowania zapisów etymologicznych w tym tekście.

Następną grupą wykazująca tendencję do ubezdźwiecznień jest grupa -ższ-. W analizowanych próbach tekstów odnaleziono 4 potwierdzenia zjawiska. Asymilacje objęły przede wszystkim stopień wyższy bądź najwyższy przymiotnika: cieffza (CresKs 680), miaffze (CresKs 680), dlufzfzy (FalZio

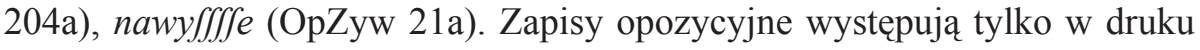
wydanym u wdowy po Unglerze: miqżjzo (CresKs 132), wyżjzey (CresKs 131), fużfzy-2 potwierdzenia (CresKs 131, 324).

Inną grupa, która podległa asymilacji w więcej niż jednym tekście, jest -dk-, odnotowana w leksemach ftotki (Wietor - 10 potwierdzeń, np. OpZyw 20a, 20b, 21a 54a) oraz prętkofcia (CresKs 680).

Pozostałe przykłady ubezdźwiecznień dotyczą bądź pojedynczych poświadczeń danej grupy, bądź poświadczeń występujących w obrębie tylko jednego tekstu. W najstarszych przejrzanych drukach, wydanych w warsztacie Hallera, odnotowano 4 zapisy z ubezdźwięcznieniem głoski szczelinowej wargowo-zębowej w grupie -św-, w wyrazie nafzfyatfcha (HalUrb 312, 313 3r.). W tekstach z tej oficyny bezwzględnie dominują jednak formy niezasymilowane, odnotowano bowiem 25 potwierdzeń z nagłosową grupa $s$ w- w prezentowanym leksemie, np. fzwathego, a ponadto 15 zapisów tej grupy w innych leksemach.

Kolejnym przykładem jest zapis wyrazu opczowanye z ubezdźwięcznioną głoską zwartą dwuwargową $p(\leq b)$. W drukach Hallera znaleziono 2 potwier- 
dzenia form zasymilowanych (HalAg 17b, 33b), natomiast nie odnotowano postaci opozycyjnych. Zapis z dźwięczną głoską $b$ wystąpił natomiast w tekście pochodzącym z oficyny Macieja Scharffenberga.

W Zywocie wszechmocnego Syna Bożego... trzykrotnie wystapił zapis leksemu naftotffy oraz jeden przykład ubezdźwięcznienia głoski z $\mathrm{w}$ formie wieccie. W wypadku grupy -dš- bez ubezdźwięcznienia zapisywano imie-

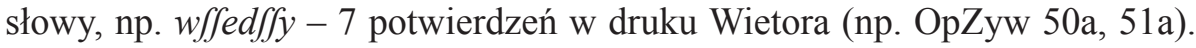
W pozostałych tekstach znalazły się jedynie dwa potwierdzenia zapisu grupy: młodffy (Tob 2) oraz fwiádffeniu (Tob 9). Oba wyrazy występują w druku Macieja Scharffenberga. Dla drugiej z omawianych grup, z głoską zwartoszczelinowa, odnaleziono 2 zapisy opozycyjne powiedzcie (OpZyw 52a), wyedczye (HalAg 70a).

W tekście Falimirza, pochodzącym z oficyny Unglera, odnotowano poje-

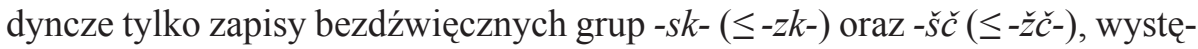
pujące w leksemach gatafzki (FalZio 200a) i mefzcziznam (FalZio 103b). Dla pierwszej grupy zapisy opozycyjne znaleziono jedynie w tekście wydanym w drukarni wdowy po Unglerze, w tym trzy dla omawianego leksemu (CresKs $323,327,328$ ) i jeden w innym: rozkofzne (CresKs 328). Drugi wyraz bez asymilacji pojawił się w druku Wietora: mężczyznámi (OpZyw 22b).

W tekście Tobias patriarcha... pojawił się zaledwie jeden przykład z ubezdźwięcznioną grupą -źć - nále c (Tob 29), w którego wypadku (zarówno leksemu, jak i grupy) nie wystapiły zapisy opozycyjne, oraz zasymilowanej grupy -bf- w formie opficie (Tob 11), dla której zapis opozycyjny znaleziono tylko w druku Wietora (OpZyw 21b).

Można zatem stwierdzić, że w zakresie asymilacji grup spółgłoskowych istniały w omawianym okresie tendencje powszechne, spotykane we wszystkich drukach O1, jak tendencja do ubezdźwięcznienia na granicy morfemów, czego szczególnym przykładem jest asymilacja głoski $z \mathrm{w}$ przedrostku roz- przed głoską bezdźwięczną rozpoczynającą następny morfem. Pozostałe formy zasymilowane to również w zdecydowanej większości przykłady ubezdźwięcznień powstałych na granicy morfemów, między rdzeniem a afiksem. Wyrazy o najwyższej frekwencji i ekstensji tekstowej w badanym materiale nie mają zapisów opozycyjnych (bez ubezdźwięcznienia), notowane są wyłącznie postaci: cięszko (12 potwierdzeń), roskosz (11). Można również wskazać pewne zwyczaje indywidualne, charakteryzujące konkretne oficyny wydawnicze. Ze względu na słabszą tendencję do ubezdźwięcznień drukarnią wyróżniająca się jest drukarnia kierowana przez Helenę Florianową Unglerową oraz oficyna Macieja Scharffenberga.

W drugim okresie badawczym odnotowano 63 zapisy potwierdzające asymilacje pod względem dźwięczności. Najwięcej, 26 przykładów, znalazło się 
w książce wydanej przez Łazarza Andrysowica. Stanowią one 2\% wszystkich grup niejednorodnych pod względem dźwięczności występujących w tym druku. W tekście pochodzącym z oficyny Mikołaja Szarfenberga w obrębie próby znaleziono 20 poświadczeń (2\%), zatem oba druki wykazują podobne tendencje ogólne w zakresie ubezdźwięcznień. W wypadku dwóch kolejnych tekstów reprezentujących $\mathrm{O} 2$ są one już mniejsze. W tekście wydanym przez Piotrkowczyka wystąpiło 11 poświadczeń (1\%), w druku Wirzbięty - 6, co stanowi zaledwie $0,6 \%$ wszystkich zapisów niejednorodnych pod względem dźwięczności grup spółgłoskowych.

Podobnie jak w wypadku O1, i w tym okresie można wyznaczyć tendencje wspólne dla wszystkich tekstów. W drukach z O2 można odnaleźć zapisy $\mathrm{z}$ ubezdźwięcznioną głoską $z \mathrm{w}$ przedrostku roz- przed następną bezdźwięczną. W najstarszym tekście tego okresu, wydanym przez Andrysowica w 1561 roku, odnotowano 24 poświadczenia asymilacji w 7 leksemach. Najliczniej potwierdzony jest wyraz rofkázáć. Znaleziono 14 zapisów z ubezdźwięcznieniem i żadnego bez asymilacji (MrowSta np. 6a, 7a, 7b, 9b, 16a, 176a). Dla pozostałych wyrazów odnotowano już zdecydowanie mniej potwierdzeń: rofterki4 przykłady (MrowSta 15a, 15b, 22b 2r.), rofkofznieyfze - 2 (MrowSta 5b, $8 b$ ) oraz pojedyncze zapisy: rofptodzenia (MrowSta 7a), rofpuftney (MrowSta 16a), rofpuśćiw/zy (MrowSta 31a), roftropniey/zy (MrowSta 32a), ale wszystkie również bez form opozycyjnych. W druku Mikołaja Szarfenberga, w obrębie próby tekstu, pojawiło się 13 zapisów z ubezdźwięcznionym $z$ w przedrostku roz- w 6 leksemach. Najwięcej potwierdzeń (4) odnotowano dla wyrazu rofpadza (SienHerb 182b, 184, 379, 578). W odniesieniu do tego wyrazu odnaleziono 2 zapisy opozycyjne (SienHerb 182b, 183b). Pozostałe leksemy zapisywano tylko w postaci zasymilowanej: rofpuść - 3 potwierdzenia (SienHerb 378 2r., 379), roftworz - 2 (SienHerb 577, 578), rofpalone - 2 (SienHerb 577b 2r.), nierofkwittey - 1 (SienHerb 576b), roftropnie - 1 (SienHerb 577b). W tekście wydanym przez Piotrkowczyka odnaleziono 9 poświadczeń ubezdźwięcznienia w 4 leksemach: rofkofzy - 5 zapisów (SkarZyw 273, 602, 603, 999 2r.), rofptynęty - 2 (SkarZyw 602 2r.) oraz pojedyncze: rofkazat (SkarZyw 602), roftopiło (SkarZyw 602). Nie odnotowano natomiast zapisów niezasymilowanych. W najmłodszym druku drugiego okresu badawczego, wydanym w oficynie Wirzbięty w 1588 roku, w obrębie próby tekstu znaleziono 5 analogicznyh przykładów ubezdźwięcznień w 2 leksemach: rofkázuie (PhilMił 21b, 40b, 42b, 61b) oraz roftherkow (PhilMił 62a). Nie odnotowano zapisów opozycyjnych. Można zatem stwierdzić, że zapisy ujawniające ubezdźwięcznienie stanowiły bezwzględną dominantę w $\mathrm{O} 2$, dodatkowo wzmocnioną, jak można wnioskować na podstawie badanego materiału, przez leksykalizację niektórych postaci, np. rofkázáć, który występuje w trzech tekstach z O2, w jednym 
z O1 - we wszystkich zapisywany jest wyłącznie w formie zasymilowanej, oraz rofkofz, występujący w dwóch tekstach z O2 oraz w jednym z O1.

Należy też zwrócić uwagę na fakt, że w drugim okresie badawczym można znaleźć zapisy z prefiksem roz- bez ubezdźwięcznienia. Są to przede wszystkim wyrazy z grupa -zs-, -zś- i -ž́-, czyli takie, w których upodobnienie pod względem dźwięczności mogłoby wywołać kolejne procesy prowadzące do redukcji grupy. W takich wypadkach, gdy zagrożona jest struktura grupy, zauważyć można tendencję do utrzymywania pisowni etymologicznej, bez uproszczeń. Tak jest w większości tekstów z O2: rozfądku - 4 potwierdzenia (np. PhilMił 42b), rozfądzániu - 1 (PhilMił 42b); rozfzerzyłá - 1 (SkarZyw 603), rozśiewat - 1 (SkarZyw 999); rozjzerzeniu - 1 (MrowSta 5b). Ponadto w tekście wydanym przez Mikołaja Szarfenberga pojawił się pojedynczy zapis rozchodzić (SienHerb 182b), także bez asymilacji, choć grupa spółgłoskowa w tym wyrazie nie była zagrożona redukcją.

Innym wspólnym dla wszystkich oficyn elementem jest tendencja do ubezdźwięczniania grupy -žk-. Asymilacja tej grupy występuje zarówno w wyrazie cięzki, co stanowi kontynuację tendencji z okresu wcześniejszego, a także sugeruje jej leksykalny charakter, jak i w innych wyrazach: wrofzke - 2 potwierdzenia (SienHerb 184b, PhilMił 41a) oraz kfiafzkach - 1 (PhilMił 41a).

Ponadto w O2 odnotowano pojedyncze zapisy: krotochfil (MrowSta 27a), sqsieckie (MrowSta 3b), ifzći (SienHerb 577b), Lebiotká (SienHerb 379), leść (SienHerb 576b), męzcżyżnam (SienHerb 183b), náleść (SkarZyw 603). W wypadku przytoczonych leksemów nie pojawiły się zapisy opozycyjne.

W tekstach drugiego okresu badawczego nie można wyróżnić wyraźnych tendencji indywidualnych. Zakres asymilacji w drukach poszczególnych oficyn jest porównywalny.

W trzecim okresie badawczym wystapiło najmniej przykładów ubezdźwięcznień. Znaleziono zaledwie 12 potwierdzeń grup zasymilowanych, co stanowi 0,3\% wszystkich zakwalifikowanych do analizy zapisów grup spółgłoskowych. Najwięcej potwierdzeń pojawiło się w tekście wydanym przez Franciszka Cezarego - 6 w 4 różnych leksemach. W druku Skalskiego, w obrębie próby, można znaleźć 4 zapisy jednego wyrazu. W Młocie na czarownice, pochodzącym z oficyny Kempiniego, odnotowano 2 poświadczenia (w 2 leksemach), natomiast w druku Piątkowskiego nie znaleziono śródgłosowego ubezdźwięcznienia. Przy tak małej liczbie zapisów trudno ustalić tendencje ogólne, wspólne dla wszystkich drukarni. Można jedynie domniemywać, że ubezdźwięcznienie w przedrostku roz- przed głoską bezdźwięczną, podobnie jak w okresach wcześniejszych, będzie zjawiskiem powszechniejszym, przykłady bowiem takie można odnaleźć w dwóch drukach - Skalskiego oraz Franciszka Cezarego: rofkazat - 4 potwierdzenia (ŁaszSum 10 2r., 33, 12), 
roftropność - 3 (BernSp 153, 154 2r.), pojedyncze: rofkazániu (BernSp 52), rofkofznego (BernSp 102), rofpamiętywáy (BernSp 151). W dwóch pozostatych tekstach asymilacje w tym przedrostku nie zostały potwierdzone, $w$ druku zaś Kempiniego pojawił się zapis: rozplynie (ZąbMł 42).

Ponadto w druku Kempiniego znalazły się grupy zasymilowane: gátafki (ZąbMł 143) i rzetfza (ZąbMł 42). Nie odnotowano dla tych leksemów zapisów opozycyjnych. Przykłady grup niezasymilowanych znane są jednak omawianemu tekstowi, ale $\mathrm{w}$ innych wyrazach: 1 poświadczenie grupy $-z k$-: męzkim (ZąbMł 221) oraz 2 poświadczenia grupy -dsz-: wyszedszy (ZąbMł 144, 225).

We wszystkich trzech okresach badawczych wystapiły również przykłady ubezdźwięcznień międzywyrazowych. Do tej grupy zostały też zakwalifikowane zapisy, w których ubezdźwięczniana lub raczej neutralizowana pod względem dźwięczności jest spółgłoska wygłosowa, mimo że w nagłosie kolejnego wyrazu znajduje się głoska dźwięczna. Zjawisko to jest specyficzną konsekwencją procesu wydawniczego, podczas którego pracownik drukarni składał tekst z wyizolowanych wyrazów, otrzymywał tym samym bezdźwięczny wygłos. W zależności od poziomu świadomości językowej oraz doświadczenia czy wzorców stosowanych w danej oficynie wybierał on jeden z wariantów pisownianych. Ogólna międzyokresowa tendencja dotycząca ubezdźwięcznień międzywyrazowych nie pokrywa się z tendencją dotyczącą asymilacji wewnątrzwyrazowych. W tym wypadku liczba zapisów wzrasta w kolejnych półwieczach. W ujęciu szczegółowym można jednak zauważyć różnice między poszczególnymi tekstami. Sygnalizowane zjawisko nie jest bowiem powszechne dla wszystkich oficyn, ale zależy od indywidualnych preferencji danej drukarni.

W O1 odnotowano najmniej ubezdźwięcznień międzywyrazowych 6 zapisów w drukach pochodzących z dwóch warsztatów: Hallera (nat tho HalPow 314 2r.) i Wietora (mosk - 2 zapisy przed dźwięczną w nagłosie kolejnego wyrazu: mofk z głowy (OpZyw 101a), wmofk wbieżáłá (OpZyw 102b) - i nalast - 2 zapisy, jeden przed dźwięczną spółotwartą rozpoczynającą następny wyraz, drugi przed bezdźwięcznym nagłosem: nienálaft iedno (OpZyw 51b), nálaft tam (OpZyw 51a)). W O2 odnotowano zdecydowanie więcej potwierdzeń - 13. Występują również w dwóch tekstach: w druku wydanym przez Andrysowica znaleziono 9 potwierdzeń, w druku Wirzbięty - 4. W Stadle malżeńskim... z ubezdźwięcznieniem zapisywano przede wszystkim wyrażenia przyimkowe, w tym 4 przed głoską dźwięczną, np. przes Dawida (MrowSta 33b) i 4 przed głoską bezdźwięczna, np. przes ftarość (MrowSta 21b), przes fwoie (MrowSta 33b). W tekście z oficyny Wirzbięty ubezdźwięczniano wygłos przede wszystkim przed głoską bezdźwięczną na- 
stępnego wyrazu (3 potwierdzenia, np. poniewasz to - PhilMił 62a, przywiost / przywabiwszy - PhilMił 62b). Odnotowano też jeden wypadek ubezdźwięcznienia przed jotą: poniewasz już (PhilMił 62a). W ostatnim z badanych okresów wystapiło 21 przykładów ubezdźwiecznień międzywyrazowych i wygłosowych. Potwierdzenia te znaleziono w drukach wydanych przez Skalskiego i Piątkowskiego. W wypadku pierwszego tekstu odnotowano 5 potwierdzeń, z czego aż 4 to ubezdźwięcznienia przed bezdźwięcznym nagłosem następnego wyrazu, np. ocofz tedy (ŁaszSum 56). Przykład neutralizacji dźwięczności stanowi zapis czemujzby (ŁaszSum 51). W wypadku drugiego tekstu na 15 potwierdzeń 6 przykładów to wyrażenia, w których następuje ubezdźwięcznienie przed bezdźwięcznym nagłosem kolejnego wyrazu, np. cżemusz ták (CichWiz 62Qv), iákosz się (CichWiz 90Z2r). Pozostałe przykłady można uznać za neutralizację wygłosu, powstałą w wyniku izolowania wyrazów przez osobę składająca tekst, np. poniewasz boi (CichWiz 60P3v). Na taki problem uwage zwraca Halina Koneczna:

Razem z upodobnieniami grup spółgłoskowych pod względem dźwięczności należy omówić zachowanie się w wygłosie wyrazu pierwotnych dźwięcznych spółgłosek właściwych. Otóż w KGn [Kazaniach gnieźnieńskich - A.Ch.] pojawia się już pisownia wedtuk, podtuk, bok 'Bóg', nok 'nóg', okrøk obok wielu innych dobrze utrzymanych dźwięcznych spółgłosek wygłosowych. W PFl [Psałterzu floriańskim - A.Ch.] zachowana została etymologiczna dźwięczność spółgłosek wygłosowych, jednak i tam pojawia się już podluk pekla i sksøk sziwich 'z ksiąg żywych', w KWŚ [Kazaniu na Wszech Świętych - A.Ch.] zapisano drap, sskat, podluk lub podluc, grzechof, w innych zabytkach XV-wiecznych spotykamy częste zapisy mros, snyek, possag, okrank. Sprawa pisowni zależała oczywiście od stopnia wykształcenia pisarza, tak np. w traktacie Parkosza nie znajdujemy ani jednego wypadku sfonetyzowanej postaci wyrazu. Należy więc przyjąć, że w języku staropolskim w XV w. parowiekowy proces ubezdźwięcznienia etymologicznie dźwięcznych głosek wygłosowych się już ustabilizował $[. . .]^{9}$.

Koneczna dodaje także, że

spółgłoski właściwe również tracą swą dźwięczność w pozycji przed wygłosową półotwartą, która także ulega w takich wypadkach ubezdźwięcznieniu, a następnie ginie. W KGn spotykamy pisownię przysetl, posetl, wysetl, spatl $[\ldots]^{10}$.

${ }^{9}$ H. Koneczna, Charakterystyka fonetyczna języka polskiego na tle innych języków słowiańskich, Warszawa 1965, s. 170.

${ }^{10}$ Ibidem, s. 171. 
Można zatem stwierdzić, że w drukach szesnasto- i siedemnastowiecznych stosuje się również takie rozwiązania, które stanowią kontynuację wcześniejszych praktyk.

W przeciwieństwie do ubezdźwięcznień wewnątrzwyrazowe udźwięcznienia należą do zjawisk incydentalnych. W każdym z trzech przeanalizowanych okresów badawczych odnotowano po jednym zaledwie przykładzie wewnątrzwyrazowego udźwięcznienia grupy spółgłoskowej. W O1 ten rodzaj asymilacji pojawił się w tekście Tobias patriarcha... wydanym przez Macieja Scharffenberga w wyrazie prozbę (prośbę) (Tob 18). Warto zaznaczyć, że w obrębie próby tekstu nie wystapiły zapisy opozycyjne tego wyrazu, podobnie jak w pozostałych tekstach pierwszego okresu badawczego. Zapisy etymologiczne bez asymilacji pojawiają się jednak w O2 i O3. W drugim okresie badawczym w druku Mikołaja Szarfenberga z 1568 roku odnotowano zapis Iáźminowego (jaśminowego) (SienHerb 577b) ${ }^{11}$, bez postaci opozycyjnych. W badanym tekście inne jednak wyrazy zapisywane są z etymologiczną grupą -śm-, jak w wyrazie uśmierza (np. SienHerb 182b). W ostatnim z badanych pięćdziesięcioleci wyraz z asymilacją odnotowano w druku Kempiniego - w imiesłowie wyniozfzy (ZąbMł 225).

Reasumując, podkreślić należy, że w badanym wycinku czasowym (wiek XVI i pierwsza połowa XVII wieku) asymilacja spółgłosek z pewnością nie należy do zjawisk masowych czy powszechnych, jednak w każdym okresie badawczym pojawiają się zapisy, w których doszło do upodobnień w obrębie grupy spółgłoskowej. Na podstawie badanego materiału obejmującego półtora wieku drukarstwa krakowskiego zaobserwować można spadkową tendencję w zakresie liczby zapisów ujawniających wewnątrzwyrazowe asymilacje pod względem dźwięczności. Najwięcej poświadczeń odnotowano w pierwszym okresie badawczym, nieco mniej w drugim, w trzecim natomiast już tylko $0,3 \%$. Najczęściej asymilacji podlega prefiks roz-, po którym występuje spółgłoska bezdźwięczna rozpoczynająca rdzeń. Odstępstwa od takiego sposobu zapisu widoczne są w drugim okresie badawczym, kiedy unika się ubezdźwięczniania głoski $z$, jeśli istnieje zagrożenie dalszymi zmianami jakościowymi oraz ilościowymi w grupie. Zmiana tej tendecji po pierwszym okresie badawczym i stopniowa eliminacja zasymilowanych zapisów spowodowana jest postępującą petryfikacją uzusu ortograficznego, eliminującą cechy typowe dla potocznej polszczyzny mówionej.

Inaczej sprawa się przedstawia w wypadku ubezdźwięcznień międzywyrazowych. W tym zakresie ogólna tendencja (międzyokresowa) stanowi, jak

${ }^{11}$ Słownik polszczyzny XVI wieku odnotował ten sam przykład. Nie pojawiły się natomiast zapisy leksemu z grupą etymologiczną. 
pokazuje materiał, odwrócenie tej panującej wśród ubezdźwięcznień śródwyrazowych: najmniej poświadczeń jest w najstarszym okresie badawczym, ich liczba wzrasta natomiast w kolejnych. Ubezdźwięcznienia międzywyrazowe mają raczej charakter indywidualny - nie występują bowiem we wszystkich tekstach. Stosowanie tego typu rozwiązań ortograficznych zależne było od uzusu panującego w konkretnej oficynie wydawniczej.

W badanych tekstach najrzadziej spotykanym typem asymilacji jest udźwięcznienie. Pojawia się z niewielką frekwencją w pojedynczych wyrazach, toteż nie można wyznaczyć tendencji ani ogólnych, ani indywidualnych dla poszczególnych drukarni.

Anna Pyrkosz

\section{Assimilations with Respect to Tone in Consonant Groups in the Polish Language of the 16th Century and the First Half of the 17th Century (on the basis of printed material from Cracow)}

The aim of the article is to present the problem of assimilation with reference to tone within consonant groups (inside words and at word boundaries) in the Polish language of the 16th century and the first half of the 17th century. Research material is analysed in three synchronic sections, making it possible to capture the dynamics of change. On the basis of the collected material, general tendencies have been determined for particular periods and dominants with reference to orthography of consonant groups, which are compared with individual orthographic solutions applied by individual publishing houses. It was possible to conclude from the results of the studies that tonal assimilations did not belong, during the analysed period, to mass phenomena, although their examples can be found in every text. Moreover, noticeable is the tendency to limit the variant character of records concerning heterogeneous consonant groups, which is expressed by the decline in the number of assimilated forms in the subsequent study periods. 
